\title{
VARIA
}

\section{OCZEKIWANIA I MOTYWACJA TRANSPLANTACYJNA POTENCJALNYCH BIORCÓW KOŃCZYNY GÓRNEJ - TEORETYCZNO-BADAWCZE STUDIUM SOCJOLOGII FENOMENOLOGICZNEJ}

\begin{abstract}
Abstrakt. Problematyka artykułu ulokowana jest na pograniczu socjologii i medycyny. Jego celem jest przedstawienie oczekiwań i motywów chorych okaleczonych deficytem ręki, które związane są $\mathrm{z}$ ich potencjalnym udziałem w zabiegu transplantacji kończyny. Kontekstem ich poznania ustanowiono sprawnościowe i wizualne doświadczanie w przeszłości ciała sfragmentaryzowanego oraz sprawnościowe i wizualne doświadczanie w przyszłości ciała zrekonstruowanego. Empiryczną podstawą tekstu są socjologiczne badania jakościowe przeprowadzone w grupie kandydatów na biorców, którzy przeszli pozytywnie kwalifikację do unilateralnego lub bilateralnego zabiegu transplantacji kończyny górnej w Polsce $(\mathrm{N}=15)$. Za teoretyczny układ odniesienia wobec tak zakreślonej tematyki badań obrano elementy socjologii fenomenologicznej Alfreda Schütza, a ściślej jego teorię motywów typu „ponieważ” i typu „żeby”. Analiza materiału empirycznego potwierdziła istnienie obu kategorii motywów w transplantacyjnym projekcie badanych potencjalnych biorców kończyny. Najistotniejszymi transplantacyjnymi motywami „ponieważ” okazały się te, które wiążą się z: wizerunkową nieakceptacją własnego ciała; wizerunkowym kalectwem społecznym; ograniczeniami sprawnościowymi ciała. Kluczowymi transplantacyjnymi motywami ,żeby” pozostają natomiast: rekonstrukcja sprawności ciała; uzyskanie estetycznego obrazu własnego ciała. W konkluzji tak sformułowanych kolejnych motywów i oczekiwań poczyniono dwa ważne ustalenia: mimo pogodzenia się badanych z ograniczeniami sprawnościowymi sfragmentaryzowanego ciała, to właśnie odbudowa sprawności pozostaje ich najważniejszym motywem transplantacyjnym; mimo zasadniczej nieakceptacji wizerunkowej sfragmentaryzowanego ciała, kwestia jego potransplantacyjnej estetyki jest w motywach badanych relatywnie mniej znacząca.
\end{abstract}

Słowa kluczowe: socjologia medycyny, transplantacja kończyny, przeszczep ręki, fenomenologia, doświadczanie ciała, motywy „ponieważ”, motywy „żeby”.

\section{Wprowadzenie}

Transplantacje zewnętrznych części ciała, takich jak ręka czy twarz, otworzyły zupełnie nową erę w transplantologii. Zabiegi te, z racji ciagłej widoczności przeszczepu, rodzą zasadniczo odmienne problemy, aniżeli przeszczepy

* Zakład Socjologii, Wydział Filologiczno-Historyczny, Akademia im. Jana Długosza w Częstochowie; e-mail:k.kowal@ajd.czest.pl 
narządów wewnętrznych, które zostają ukryte głęboko pod powłokami skórnymi ciała biorcy. Inny jest też rodzaj motywacji chorych przystępujących do tego rodzaju przeszczepień. Niezwykle rzadko wszak odbywają się one ze wskazań życiowych. U podstaw motywacji transplantacyjnej potencjalnego biorcy leży natomiast przede wszystkim poprawa jego komfortu życia. I to właśnie w kontekście motywacji chorych poddających się zabiegowi transplantacji ręki pojawia się najwięcej wątpliwości i pytań co do zasadności tych przeszczepień z punktu widzenia możliwych do uzyskania efektów zastosowania tej metody leczenia w relacji do negatywnych konsekwencji potransplantacyjnej terapii immunosupresyjnej. Ponieważ wspomniane wątpliwości i pytania stawiają nierzadko sami lekarze uczestniczący w procedurze kwalifikacji chorych do tych zabiegów, prezentowany tekst wraz ze stanowiącymi o jego podstawie empirycznej badaniami zyskuje walor aplikacyjny, który ma przybliżyć do siebie świat medycyny i socjologii. Na pograniczu tych dwóch dyscyplin ulokowana jest problematyka niniejszej pracy, której celem ma być przedstawienie motywów i oczekiwań chorych okaleczonych deficytem ręki związanych z ich potencjalnym udziałem w zabiegu transplantacji kończyny górnej. Prezentowany projekt mieści się w socjomedycznym nurcie badawczym, realizującym postulat ucieleśnienia przedmiotu badań socjologii, tłem czynionych poniżej analiz staje się wizualne i sprawnościowe doświadczanie ciała.

\section{Teoretyczne i metodologiczne podstawy badań}

Główne pytanie, na które poszukiwałam odpowiedzi w toku procesu badawczego, dotyczyło poznania motywów i oczekiwań potencjalnych biorców kończyny górnej w kontekście sprawnościowego i wizualnego doświadczania w przeszłości ciała sfragmentaryzowanego oraz sprawnościowego i wizualnego doświadczania $\mathrm{w}$ przyszłości ciała zrekonstruowanego. Zgodnie z teoretycznym układem odniesienia wobec tak zakreślonej problematyki badań, za który obrałam elementy socjologii fenomenologicznej Alfreda Schütza (1899-1959)2, w badaniu skoncentrowałam się na subiektywnej rzeczywistości chorych jako tej, która warunkuje sposób doświadczania przez nich własnego ciała. Chcąc poznać oczekiwania i motywy związane z planowanym poddaniem się przez badanych przeszczepieniu kończyny górnej, odwołałam się do poznania ich

${ }^{2}$ Socjologia fenomenologiczna jest, zgodnie z tym, co pisze Jerzy Szacki, „najbardziej radykalnym kierunkiem socjologii humanistycznej, interpretatywnej czy też [...] rozumiejącej”. O wkładzie w jej rozwój A. Schütza u tego samego autora czytamy: „,...] uczynił bodaj najwięcej dla ujawnienia socjologicznych implikacji fenomenologii Husserla i uczynienia jego koncepcji «świata przeżywanego» fundamentem swoistej ontologii społecznej, bez której trudno sobie dziś wyobrazić nie tylko socjologię fenomenologiczną, lecz również współczesną socjologię humanistyczną w ogólności” (S z a c k i 2006: 863, 865). 
doświadczeń i interpretacji świata życia codziennego (work a daily life), który stanowi jedną z najważniejszych kategorii w koncepcji socjologii fenomenologicznej A. Schütza.

Empiryczną podstawę tekstu stanowią socjologiczne badania jakościowe przeprowadzone przez autorkę $\mathrm{w}$ grupie potencjalnych biorców kończyny górnej $(\mathrm{N}=15)$, którzy obecnie wyczerpują populację chorych oczekujących na ten rodzaj cielesnej rekonstrukcji w Polsce ${ }^{3}$. Wśród badanych znaleźli się potencjalni biorcy ręki reprezentujący dwie grupy chorych: 1) chorzy, którzy utracili kończynę(y) na skutek urazu mechanicznego; 2) chorzy z wrodzoną wadą braku ręki. Każdy z badanych chorych przeszedł pozytywnie kwalifikację do unilateralnego (jednostronnego) lub bilateralnego (dwustronnego) zabiegu transplantacji kończyny górnej w Oddziale Chirurgii Ogólnej Szpitala Powiatowego im. św. Jadwigi Śląskiej w Trzebnicy. Jest to jeden z wiodących ośrodków transplantacji kończyn na świecie i pierwszy ośrodek realizujący te przeszczepienia w Polsce.

Zebranie materiału empirycznego stało się możliwe dzięki przeprowadzeniu z każdym z badanych potencjalnych biorców kończyny górnej wywiadu swobodnego, ukierunkowanego według typologii wywiadów Jana Lutyńskiego (Przybyło w ska 1978, za: K o ne cki 2000: 169). Osoba prowadząca wywiad (w przypadku każdego z respondentów była to autorka tekstu) dysponowała tutaj listą potrzeb informacyjnych, które dotyczyły takich elementów rzeczywistości życia codziennego badanych jak: praca, ruchy ciała, manipulowanie przedmiotami, czynności nawykowe, higiena i inne działania skierowane na ciało. Istotnym wątkiem wywiadu było również to, w jaki sposób ciało badanych komunikuje się z otaczającym światem społecznym poprzez określone gesty skierowane na ciała innych ludzi. Wywiad był prowadzony zgodnie z zaleceniami techniki wywiadu rozumiejącego Jeana-Claude'a K a u fma n n a (2010). Odwołując się w nim do subiektywnego punktu widzenia respondentów, badaczka pozostawała otwarta na kategorie, w których badani będą interpretowali swoje cielesne działania. W trakcie prowadzenia wywiadu nie rezygnowała jednak $\mathrm{z}$ równoczesnego czynienia obserwacji ciała badanego, jego postawy, ruchów, gestów, układu poszczególnych części ciała. Miało to pozwolić skorelować ze sobą świat subiektywnych przeżyć badanych ze światem obiektywnym, czyli jego fizyczną cielesnością. Oba te światy uznała za równie warte poznania. Zastosowane metody badań umożliwiły przyjrzenie się temu, jak w wymienionych aspektach rzeczywistości dnia codziennego badani doświadczają swojej cielesności, co w istocie jest przeżywaniem ciała, w następstwie którego gromadzą wiedzę o ciele, by ostatecznie własne ciało zrozumieć.

${ }^{3}$ Dane na dzień 9.11.2016 r. pochodzą od koordynatora transplantacyjnego ze Szpitala Powiatowego im. św. Jadwigi Śląskiej w Trzebnicy. 


\section{Socjodemograficzny portret badanych}

W grupie badanych potencjalnych biorców kończyny górnej $(\mathrm{N}=15)$ znalazło się 11 mężczyzn i 4 kobiety. Przedział wiekowy, w którym znajdowali się respondenci jest dość szeroki. Najmłodszy badany w chwili przeprowadzania z nim wywiadu miał 18 lat, najstarszy 55 lat. Dane dotyczące stanu cywilnego kandydatów na biorców kończyny wskazują, że 8 osób z tej grupy żyło w stanie wolnym, 5 badanych pozostawało w związkach małżeńskich, jedna osoba była rozwiedziona, a jedna owdowiała. Co się tyczy miejsca zamieszkania badanych, to 7 badanych zadeklarowało się jako mieszkańcy wsi, 4 badanych zamieszkiwało miasto powyżej 100 tysięcy mieszkańców, 2 kolejnych miasto liczące powyżej 50 tysięcy do 100 tysięcy mieszkańców i tyleż samo miasto do 50 tysięcy mieszkańców. Wśród potencjalnych biorców przeszczepu ręki 6 osób posiadało wykształcenie średnie, 4 wykształcenie podstawowe, 3 zasadnicze zawodowe, a 2 wyższe. $Z$ analizy odpowiedzi udzielonych na pytanie metryczki dotyczące sytuacji zawodowej badanych wynika, że jest ona dość zróżnicowana. Obok respondentów aktywnych zawodowo, pracujących zarówno w prywatnych firmach, jak i prowadzących własną działalność gospodarczą -6 osób, w badanej grupie znalazły się osoby niepracujące zawodowo, które z racji na swój stan zdrowia korzystały ze świadczeń rentowych -6 osób. Wśród pozostałych badanych 2 osoby uczyły się w szkole średniej, a jedna studiowała. Dane uzyskane w odpowiedzi na pytanie związane ze sferą religijności badanych pokazują że wśród kandydatów na biorców ręki dominuje postawa zaangażowania w kwestie religijne. I tak, 13 badanych przyznało, że są osobami wierzącymi i uczestniczącymi w obrzędach religijnych. Wszyscy ci badani wskazali, że wyznawaną przez nich religią jest chrześcijaństwo rzymskokatolickie. Osobami areligijnymi nazwało się 2 respondentów.

Co się tyczy rodzaju amputacji, to najwięcej badanych doświadczyło jednostronnej urazowej amputacji kończyny dominującej, którą w przypadku tych 7 osób była kończyna prawa. Kolejnych 6 badanych żyje z obustronnym deficytem rąk, natomiast 2 spośród badanych urodziło się z jednostronnym deficytem prawej kończyny. Istotna pozostaje także informacja na temat długości okresu funkcjonowania chorego z deficytem kończyn(y). I tak, 7 chorych żyje z tym deficytem nie dłużej niż 10 lat, 6 powyżej 10 do 20 lat, a 2 chorych funkcjonuje w ciele okaleczonym ubytkiem kończyn(y) dłużej niż 20 lat.

Najbardziej znaczące z punktu widzenia problematyki badań dane socjodemograficzne zestawione $\mathrm{z}$ rodzajem amputacji występującej $\mathrm{u}$ chorego oraz informacją o długości okresu funkcjonowania $\mathrm{z}$ deficytem kończyn(y) przedstawiono w tabeli 1. 
Tabela 1. Cechy określające status badanych jako potencjalnych biorców kończyn(y) górnej

\begin{tabular}{|c|c|c|c|c|}
\hline Lp. & Płeć & Wiek & Rodzaj amputacji kończyn(y) & $\begin{array}{c}\text { Długość okresu funkcjonowania } \\
\text { z deficytem kończyn(y) }\end{array}$ \\
\hline 1. & M & 55 lat & $\begin{array}{l}\text { jednostronna urazowa } \\
\text { amputacja prawej kończyny }\end{array}$ & 8 lat \\
\hline 2. & K & 22 lata & $\begin{array}{l}\text { dwustronna urazowa amputacja } \\
\text { kończyn }\end{array}$ & 7 lat \\
\hline 3. & $\mathrm{~K}$ & 33 lata & $\begin{array}{l}\text { dwustronna urazowa amputacja } \\
\text { kończyn }\end{array}$ & 19 lat \\
\hline 4. & M & 40 lat & $\begin{array}{l}\text { dwustronna urazowa amputacja } \\
\text { kończyn }\end{array}$ & 6 lat \\
\hline 5. & K & 55 lat & $\begin{array}{l}\text { dwustronna urazowa amputacja } \\
\text { kończyn }\end{array}$ & 8 lat \\
\hline 6. & M & 46 lat & $\begin{array}{l}\text { dwustronna urazowa amputacja } \\
\text { kończyn }\end{array}$ & 42 lata \\
\hline 7. & M & 40 lat & $\begin{array}{l}\text { jednostronna urazowa } \\
\text { amputacja prawej kończyny }\end{array}$ & 19 lat \\
\hline 8. & M & 40 lat & $\begin{array}{l}\text { jednostronna urazowa } \\
\text { amputacja prawej kończyny }\end{array}$ & 11 lat \\
\hline 9. & M & 36 lat & $\begin{array}{l}\text { jednostronna urazowa } \\
\text { amputacja prawej kończyny }\end{array}$ & 5 lat \\
\hline 10. & M & 41 lat & $\begin{array}{l}\text { jednostronna urazowa } \\
\text { amputacja prawej kończyny }\end{array}$ & 18 lat \\
\hline 11. & M & 42 lata & $\begin{array}{l}\text { jednostronna urazowa } \\
\text { amputacja prawej kończyny }\end{array}$ & 21 lat \\
\hline 12. & $\mathrm{~K}$ & 18 lat & $\begin{array}{l}\text { jednostronny wrodzony deficyt } \\
\text { prawej kończyny }\end{array}$ & 18 lat \\
\hline 13. & M & 33 lata & $\begin{array}{l}\text { dwustronna urazowa amputacja } \\
\text { kończyn }\end{array}$ & 6 lat \\
\hline 14. & M & 19 lat & $\begin{array}{l}\text { jednostronny wrodzony deficyt } \\
\text { prawej kończyny }\end{array}$ & 19 lat \\
\hline 15. & M & 27 lat & $\begin{array}{l}\text { jednostronna urazowa } \\
\text { amputacja prawej kończyny }\end{array}$ & 3 lata \\
\hline
\end{tabular}

Źródło: badania własne (2014-2016). 


\section{Fenomenologiczna konceptualizacja problematyki badań}

Według A. S c h ü tza, działaniem jest „ludzkie postępowanie, uprzednio obmyślone przez aktora, to znaczy postępowanie oparte na z góry przyjętym projekcie" (2006: 877). W odniesieniu do omawianego problemu działaniem ma być poddanie się przeszczepieniu kończyny wraz z poprzedzającym go etapem badań diagnozująco-kwalifikacyjnych, co oznacza, że jest to ten typ działania, który zachodzi w wyniku jego realizacji, a nie zaniechania (S c h üt z 2012: 131). Warto w tym miejscu jednak uściślić, że biorca nie uczestniczy w tym działaniu sam, co znaczy, że nie jest jego jedynym realizatorem. Nie może on bowiem sam przeprowadzić transplantacji kończyn(y).

Potencjalny udział badanych w zabiegu transplantacji kończyny będzie działaniem jawnym (overt), które ,jest zawsze zaprojektowane i zamierzone" (S ch ütz 2012: 131). Oczywiście momentem, w którym stanie się ono jawne będzie wezwanie biorcy do szpitala, ale o częściowym jego ujawnieniu w zewnętrznym świecie możemy mówić już w chwili poddania się przez kandydata procedurze kwalifikacji do przeszczepienia kończyny. O jawnym typie działania $\mathrm{S} \mathrm{ch} \mathrm{üt} \mathrm{z} \mathrm{pisze,} \mathrm{że} \mathrm{„musi} \mathrm{być} \mathrm{poprzedzone} \mathrm{aktem} \mathrm{woli}{ }^{4}$ przekształcającym projekt w zamiar oraz wewnętrzną komendą «Zaczynajmy!»" (2012: 131). Celowy charakter nadaje działaniu biorcy przystapienie do procedury kwalifikacji na biorce kończyny górnej. I to właśnie poddanie się tej procedurze ewaluacji kandydata na biorcę pozwala $\mathrm{w}$ nim widzieć , antycypowaną, dodatkową intencję realizacji projektu" (S chütz 2012: 135). To jeden z warunków, choć nie jedyny, który odróżnia projektowanie od fantazjowania. Następnym warunkiem jest „wykonalność projektu, który może zostać przekształcony w zamierzenie" (Sch ütz 2012: 135). O tym, że sam zabieg transplantacji ręki jest wykonalny, co znaczy, że leży w zasięgu możliwości profesjonalistów medycznych, przekonują skutecznie przeprowadzone dotychczas przeszczepienia tego narządu. Co więcej, o tym, że zabieg ten jest wykonalny w przypadku konkretnego chorego, ma świadczyć spełnienie przez niego kryteriów kwalifikacji do przeszczepienia. Ten rodzaj projektowania możemy zatem nazwać za A. S c hützem „fantazjowaniem w obrębie danych [...], a ściślej narzuconych ram, narzuconych poprzez samą rzeczywistość, w której przeprowadzone zostanie zaprojektowane działanie" (2012: 135). Inicjatywa poddania się przeszczepieniu kończyny górnej odbywa się w trybie myślenia potencjalnego, a nie życzeniowego, które jest właściwe fantazjowaniu. Dlatego też badani chorzy nazywani są potencjalnymi biorcami przeszczepu kończyny górnej i tak też są traktowani w poniższych analizach. Zgodnie z ujęciem fenomenologicznym potencjalność projektu chorych oznacza, że posiadaja oni środki do realizacji swojego celu. Ich dostępność ma właśnie potwierdzać

${ }^{4}$ Samo pojęcie ,aktu woli” (voluntative fiat) A. Schütz zaczerpnął od Williama Jamesa (S chütz 2012: 131). 
przeprowadzona z pozytywnym wynikiem procedura kwalifikacji do zabiegu transplantacji kończyny górnej. Owymi środkami pozostają nie tylko te potwierdzone na etapie kwalifikacji kryteria dotyczące wieku, rodzaju amputacji oraz stanu zdrowia fizycznego i psychicznego chorego, ale także posiadane wsparcie społeczne i odpowiednie warunki socjalno-bytowe chorego. Większość z tych środków powinna zostać oceniona jako pozostająca w aktualnym zasięgu chorego. Niektóre z nich, na przykład te, które dotyczą zaplecza rodzinnego oraz sytuacji materialnej chorego mogą znajdować się w potencjalnym zasięgu badanych. Potencjalność projektu wymaga zdaniem S ch ütza, „by nie urozmaicać moich fantazji takimi elementami, które znajdują się poza moją kontrolą" (2012: 135). Mowa tutaj o budowaniu przez potencjalnych biorców nierealistycznej motywacji związanej z transplantacją ręki. I wreszcie, z fenomenologicznego punktu widzenia zaprojektowane działanie wymaga, aby „rozważyć wszelkie szanse i ryzyko, zgodnie z moją obecną wiedzą na temat możliwych, podobnych zdarzeń w świecie społecznym" (S c h üt z 2012: 135). Owe szanse i ryzyko oceniane są w przypadku potencjalnych biorców kończyny w odniesieniu do przeprowadzonych już tego typu przeszczepień nie tylko w Polsce, ale i na świecie, w czym pomagają bez wątpienia chorym profesjonaliści medyczni. Chodzi tutaj o działania przeszłe, choć nie jest konieczne dla realizacji projektu, aby posiadać samemu doświadczenia podobnych działań. $\mathrm{W}$ istocie doświadczenie przeszczepienia kończyny było udziałem tylko jednego spośród badanych. W fenomenologicznym pojęciu projektowania istotna pozostaje ,implikacja, zgodnie z którą projektowane działanie, oraz jego środki i cele, pozostają zgodne i spójne z tymi typowymi elementami sytuacji, które [...] gwarantowały nam już w przeszłości wykonalność (jeśli nie sukces) «typowo» podobnych działań" (S c hütz 2012: 136). Reasumując, potencjalny biorca musi uczynić z transplantacji kończyny cel, tak aby jego udział w tym zabiegu nie pozostał na etapie fantazjowania. Każdy z kandydatów na biorcę kończyny musi poddać się procedurze diagnozującej, a następnie kwalifikującej do zabiegu, co będzie oznaczało, że pojawiła się u niego intencja realizacji tego projektu działania, jakim jest poddanie się zabiegowi przeszczepienia ręki. Dokonane działanie, które A. S c h ütz nazywa czynem będzie już oznaczać faktyczne poddanie się zabiegowi transplantacji i uzyskanie $\mathrm{w}$ jego rezultacie zrekonstruowanego, kompletnego ciała (2012: 131).

\section{Analiza materiału empirycznego}

W poniższych rozważaniach, których ramy stanowi teoria motywów A. Sch ütza, staram się korzystać z niej tak, aby nie stracić z oczu tego, co najważniejsze, a więc relacji podmiotu, która jako wiedza potoczna będąca ,interpretacją interpretacji” rzeczywistości społecznej ma być ,jedynie możliwym punktem wyjścia refleksji naukowej” (2006: 864). W odkrywaniu tej pierwotnej 
rzeczywistości świata przeżywanego $(\text { Lebenswelt })^{5}$ przez potencjalnych biorców ręki, interesowało mnie ciało badanych jako ciało doświadczane w relacji do przestrzeni ich życia, ludzi i przedmiotów, które znajdują się w sferze ich manipulacji. Jedną z centralnych kategorii analiz była bowiem codzienna aktywność badanych, w tym przede wszystkim działania wymagające ruchów ciała (working). Zgodnie z założeniami perspektywy fenomenologicznej ciało ludzkie zostaje tutaj potraktowane jako źródło wiedzy i doświadczenia.

Analiza materiału empirycznego będąca w istocie analizą subiektywnego świata przeżyć badanych doprowadziła do wyłonienia dwóch grup motywów transplantacyjnej rekonstrukcji ciała: 1) motywów typu „ponieważ”, których sensem jest odwołanie się do przeszłych doświadczeń chorego, a które skłaniają go do poddania się temu zabiegowi; 2) motywów typu ,żeby”, które dotyczą tego, co chorzy chcą w przyszłości osiagnąć dzięki poddaniu się transplantacji ręki. Zaproponowana kolejność ich omawiania wynika z tego, że motywy „żeby” wypływają z motywów „ponieważ”. Poznanie tych motywów jest nieodzowne dla zrozumienia istoty doświadczania przez badanych ciała okaleczonego deficytem kończyny w jego wymiarze wizualnym i sprawnościowym.

\subsection{Transplantacyjne motywy ,ponieważ”}

Zgodnie z rozumieniem motywów „ponieważ” proponowanym przez A. S c h üt z a, pomysł przystapienia do zabiegu transplantacji kończyny, którego celem ma być odzyskanie kompletnej formy ciała w przypadku każdego z badanych podyktowany musiał być ,jego osobistą sytuacją albo - mówiąc dokładniej - jego historią życia, osadzoną w osobistych uwarunkowaniach” (2012: 133).

\subsubsection{Wizerunkowa nieakceptacja wlasnego ciala}

Choć biograficzna sytuacja każdego z badanych jest niepowtarzalna, ich wspólną cechą która pozostaje bez związku z długością czasu, w którym każdy z nich funkcjonuje z deficytem kończyn(y) jest głęboka nieakceptacja własnego ciała. Jej przejawem jest postawa swego rodzaju buntu przed wizerunkową adaptacją do życia w ciele z brakującymi kończynami. Chorzy w otwarty sposób przyznają że nie tylko nie potrafia, ale i nie chcą przyzwyczajać się do obrazu swojego ciała bez rąk. Ich postawę należałoby raczej nazwać tolerowaniem sytuacji poprzez jej znoszenie licząc, że w niedługim czasie odzyskają kompletną formę ciała. Dlatego, nie zamierzają wkładać żadnego świadomego wysiłku w to, aby ostatecznie zaakceptować swoje ciało. Tę pracę uważają za zbyteczna, wszak ich obecna forma ciała jest tylko tymczasowa:

O przeszczepach rak dowiedziałam sie już na OIOM-ie. Jest to dla mnie oczywiste, że do tego dązę i zrobię wszystko, żeby to osiagnać. To jest dla mnie priorytet. Ja się nie przygotowuję do

${ }^{5}$ Autorem tego pojęcia, jak i całej koncepcji świata przeżywanego (Lebenswelt) jest Edmund Husserl, którego filozofia w istotny sposób przyczyniła się do narodzin socjologii fenomenologicznej. 
tego, że będę żyć bez rak, ja się przygotowuję caly czas mentalnie do przeszczepu. Ja cały czas żyję $w$ takim zawieszeniu, dażę do przeszczepu, bo tylko on może mi dać te ręce z powrotem. Tak nie będzie cały czas, jak jest teraz i nie pozwalam sobie myśleć, że nigdy nie będzie tego przeszczepu. To się musi zmienić i nie zawsze tak będzie. Nie godzę się na taki stan mojego ciała. (kobieta, 22 lata)

Bez względu na to, czym uwarunkowany jest deficyt kończyn(y), bycie posiadaczem niekompletnego ciała jest postrzegane jako życiowa tragedia i poważna strata cielesna. Badani mocno odgradzają się od przeżywania swojego ciała, zdają się go nie reflektować. W owej negacji ciała, można by nawet powiedzieć swego rodzaju ucieczce od własnej cielesności, sporą trudność stanowiło dla niektórych opisanie swojego ciała w jego obecnej postaci. Badani dostrzegają w nim przede wszystkim brak ręki. Wygląd własnego ciała, także w jego częściach zdrowych i kompletnych, nie ma dla badanych żadnego znaczenia. Codzienna konfrontacja z okaleczonym ciałem jest źródłem ich rezygnacji i niechęci do przejawiania dbałości o nie:

To moje ciało jest jakie jest, tu już nic nie pomoże. Teraz to już jaki by człowiek nie byt, jakby nawet zmienit gabaryty, to i tak wszystko na nic. Nawet jakbym teraz jeszcze uróst do dwóch metrów, to i tak to wszystko jest bez sensu. Nie da się teraz być zadowolonym z wygladu, cokolwiek by się nie robiło. Czy bym dbat o to ciało, czy nie, to i tak dla wygladu jest to bez różnicy. (mężczyzna, 27 lat)

Nic już nie zrobię z tym ciałem. Kompletnie nic. Wyglad $w$ ogóle dla mnie obecnie nie jest ważny. Mężczyźni staraja się przecież tė̇ być atrakcyjni, bo przecież stare przysłowie mówi: „,jak cię widzq, tak cię pisza”. Ale nie mam takiej motywacji, jak kiedyś, żeby ćwiczyć, żeby coś robić z ciatem. A kiedyś ćwiczyłem, zdrowo żyłem i nie pozwalałem sobie, żeby się zdziadzieć. A teraz nie robię nic i nie czuję sie już atrakcyjny. Poza tym nie mam na nic sity, czuję sie jak dziadek z tym swoim ciatem, szybko się męczę, wcześnie chodzę spać. (mężczyzna, 40 lat)

Typowe dla motywów „ponieważ” zwrócenie w stronę przeszłości obejmowało też prośbę badaczki o cofnięcie się do czasu sprzed amputacji, co dotyczyło tych chorych, u których deficyt kończyn(y) jest wynikiem doznanego urazu. Przyjrzenie się swojej relacji z ciałem w tym czasie, w kontekście podjętej już decyzji i starań związanych z poddaniem się transplantacji, miało pomóc uchwycić kolejny autentyczny motyw ,ponieważ”. Wśród badanych znalazły się bowiem osoby, które przed amputacją kończyn(y) były silnie skoncentrowane na swoim ciele. $\mathrm{Z}$ nieskrywanym w swojej narracji żalem badani ci opowiadali o wszystkich zabiegach skierowanych na ciało, wpisanym w ich codzienność reżimie pracy nad doskonaleniem jego formy i kondycji:

Cały czas ćwiczytem, chodziłem na siłownię, lubiłem dbać o ciało. Poza tym jeszcze ćwiczytem boks, latałem samolotem, jeździłem motocyklem. Zawsze podobały mi się tatuaże, no to sobie w końcu zrobitem kilka. Na tej ręce, którq straciłem w wypadku też miatem fajny tatuaż. (mężczyzna, 40 lat)

Przed wypadkiem czułem się młodo i chciałem wygladać młodo. Czułem się atrakcyjny. Miatem fajna mase mięśniowa bo ćwiczyłam codziennie na siłowni. Zawsze znajdowatem czas 
na ćwiczenia, bytem bardzo aktywny fizycznie. Nie potrafitem się zmęczyć. Zdrowo się odżywiałem, troche przybratem na wadze, bo wcześniej miatem niedowagę. Rzuciłem palenie i to wtaśnie sport mi w tym bardzo pomógt. A tak poza tym żadnego alkoholu, czy innych używek. Dobrze się czułem w swoim ciele. Dużo przygotowywatem się fizycznie do jazdy na motorze, bo w tym roku, w którym miałem wypadek, miałem ściagać ze Stanów Cruisera. To jest bardzo duży motor. Marzyłem o tym motocyklu. (mężczyzna, 40 lat)

Ten zapał do aktywności fizycznej badani stracili wraz z utratą kończyny. Porzucili wszystkie te formy aktywności, które wymagałyby koncentrowania się na ciele. Zaprzestanie dbałości o ciało w jego wymiarze wizerunkowym i kondycyjnym tylko jednak spotęgowało niezadowolenie i dyskomfort badanych, którego źródłem mają być kolejne cielesne ułomności jak nadwaga czy utrata gibkości ciała. Doświadczana przez badanych brzydota cielesna nie ma zatem swojego źródła wyłącznie w deficycie kończyn(y), choć ten w sposób najbardziej dostrzegalny wpływa ujemnie na ich somatopercepcję.

Chorzy, jak sami przyznaja, czują się źle z obecnym kształtem ciała. Niezależnie od tego, czy utracili kończynę, czy też jej deficyt ma charakter wrodzony, mimo prób ucieczki od fizycznego ciała, pozostają silnie skoncentrowani na jego materialnym wymiarze. Postrzegają i definiują własne ciało przede wszystkim przez pryzmat braku ręki. Odczuwany z tego powodu dyskomfort estetyczny pojawia się u badanych przede wszystkim w sytuacjach obcowania ze swoją cielesnością w trakcie czynności higienicznych. Jak przyznają, niezwykle rzadko przyglądają się swojemu ciału w lustrze. Przed konfrontacją z okaleczonym ciałem doświadczają strachu, a kiedy ona już nastapi towarzyszy im poczucie obcości swojego ciała. Przy czym nie chodzi tutaj tylko i wyłącznie o zewnętrzne postrzeganie okaleczonych fragmentów ciała, ale także ich doświadczanie zmysłowe. Treścią tych ostatnich jest wrażenie obumarcia kikuta wraz z częściami ciała do niego przyległymi, jak nazywają to sami badani „braku w nich życia”. Doznania te potęguje uczucie zimna w tych częściach ciała:

Nie patrzę na siebie w lustrze. Boję się popatrzeć na tę rękę, naprawde, szczerze. W ogóle moje ciało jest takie dziwne, bo cała ta część ciała (tu respondent wskazuje na okolicę barku i ramię powyżej kikuta - przyp. badaczki) jest taka zimna, jakby tu w ogóle krązenia nie było. (mężczyzna, 36 lat)

U badanych potencjalnych biorczyń przeszczepu kończyny brak rąk implikuje negatywną autodefinicję jako kobiety. Zubożenie ich poczucia kobiecości wynika ze szpetnego we własnej ocenie wizerunku ciała, ale też niemożności estetycznego stylizowania ciała poprzez wykonywanie makijażu, fryzury czy kosmetykę paznokci. Badane ubolewają nad tym, że w obecnej formie ciała nie mogą już dbać o nie w takim stopniu, jakby tego pragnęły. Jedna z badanych kobiet, która funkcjonuje z obustronnym deficytem kończyny górnej, tak oto opisuje estetykę i seksualność swojego niekompletnego ciała:

Ja urodziłam czworo dzieci, ale nigdy nie miałam obwistych piersi. Ja po każdej wieczornej toalecie robiłam takie ćwiczenia, że opierałam sięo... tak... (tu badana demonstruje ćwiczenie 
- przyp. badaczki) o ścianę i ćwiczyłam. A po wypadku, oprócz tego, że jak wróciłam ze szpitala to się okazało, że utyłam dwadzieścia kilogramów, to jeszcze piersi mi stracity ksztalt i jędrność. Zawsze byłam bardzo zadbana, jak gdzieś szłam, to makijaż miałam zrobiony, paznokcie pomalowane u rą i u nóg, skóra na stopach, żeby nie była popękana. Wszystko miałam zrobione. Teraz się nie potrafię wymalować, bo przecież wszystko przy mnie robi syn. (kobieta, 55 lat)

W obliczu silnej identyfikacji kobiet ze swoją cielesnością, deficyt ręki nie może być doświadczany inaczej niż zranienie kobiecej tożsamości.

\subsubsection{Wizerunkowe kalectwo społeczne}

Utrata ręki powoduje u chorych również zachwianie pewności siebie i to nie tylko w realizacji określonych czynności związanych z zawodową czy codzienną aktywnością, ale także w sferze interakcji międzyludzkich. Badani doświadczają przykrych w ich ocenie stanów emocjonalnych w sytuacji pozbawionych dyskrecji spojrzeń i natarczywych pytań związanych z niepełną formą ciała. Stale odczuwany dystans ze strony innych ludzi, a nawet zauważalny lęk przed wejściem w bliską relację z osobą niepełnosprawną jest źródłem samotności badanych i poczucia bycia nierozumianym przez otoczenie społeczne. Niektórzy z badanych mówili o doświadczanej przez nich złości i zniechęceniu do wchodzenia w kontakty z ludźmi. Zwłaszcza, że wielu z nich spotkało się z jawną nieakceptacją wyglądu swojego ciała. Badani natomiast tym bardziej czują się w wymiarze wizerunkowym ułomni cieleśnie, im częściej są tak postrzegani przez innych ludzi. Jest to zatem w dużej mierze kalectwo wizerunkowe, które jest ściśle powiązane ze społecznym funkcjonowaniem chorego:

Wśród ludzi to ja się na dzień dzisiejszy czuję nieswojo, zwłaszcza wtedy, jak wszyscy się na mnie patrzq. Żona mi nawet mówi, że ludzie się za mnq odwracaja, jak mam zły dzień, to im coś powiem dosadnie. Nie wiem już jak mam się ubierać, bo ludzie zawsze znajda powód, żeby się odwrócić. Nie mogę się do tego przyzwyczaić, że ludzie na mnie patrza. W swoim mieście czuję się bardzo źle. Wszyscy tu mnie znaja i caty czas patrza tylko na te ręce. Do pracy też jak wrócitem to wszyscy tylko na tych rękach się skupiali, jakbym w ogóle nie miat mózgu, jakby razem z tymi rękami też mózg mi wciagnęto do tej prasy. Niekiedy jakieś uwagi byty do mnie, tak jakbym ja juz niczego nie potrafit, bo nie mam rak, jakbym byt chory psychicznie wręcz. (mężczyzna, 40 lat)

W obliczu takich doświadczeń badani nabierają przekonania, że ludzie oceniają ich przede wszystkim przez pryzmat posiadanego deficytu cielesnego. Nawet jednak ci badani, którzy nie doświadczyli jakiejkolwiek formy dezaprobaty z powodu swojego ubytku cielesnego, czują się niepewnie w kontaktach towarzyskich, zwłaszcza jeśli mają one miejsce w szerokim gronie nowo poznanych osób. Przebywanie wśród ludzi, których kształt i forma ciała poprzez spełnienie norm biologicznych upodabnia ich fizycznie do siebie, przypominało respondentom, że ich własne ciało jest inne. Dlatego z reguły unikają oni takich spotkań, a jeśli już się na nich pojawiają, starają się poprzez odpowiednie zarządzanie swoim ciałem, aby ich deficyt cielesny pozostawał niezauważony. Obawy przed stygmatyzacją 
skłaniają badanych nie tylko do kamuflowania braku kończyny poprzez noszenie odpowiednich ubrań, ale nade wszystko do protezowania własnego ciała. Przyznają oni jednocześnie, że po protezę sięgają tylko i wyłącznie w podyktowaniu względami estetyczno-wizerunkowymi, wówczas gdy, jak to określają, chcą „,być w całości". W ten sposób zyskują poczucie bezpieczeństwa w przestrzeni publicznej. Znamienna w tym kontekście jest wypowiedź respondenta, który nie krył swojej radości w sytuacji, gdy w po założeniu protezy był mylony ze swoim pełnosprawnym bratem bliźniakiem:

Kupitem protezę, bo mi mówili, że nic nie będzie różnicy z ręka, że ona jest taka podobna $w$ wygladzie do skóry ręki. I faktycznie przyjrzatem się, to prawie w ogóle nie było widać różnicy, zyly było nawet na niej widać, byty podobne do moich paznokcie, tylko tyle, że to guma byta na wierzchu, a w środku sq pręty. Na poczqtku ona mi się bardzo podobała. Założyłem sobie protezę, na to sweter, kurtkę, no to kurczę... mówię... rękę mam! Nie mogłem się nacieszyć, że rękę mam. No i nawet nasza sklepowa jak przyszedtem od razu w ten pierwszy dzień z protezq do sklepu, to myślała, że to przyszedt mój brat bliźniak. Pomyliła się, a ja stałem od niej tylko kilka metrów. (mężczyzna, 42 lata)

Badani sami przed sobą nie chcą jednak poprawiać w ten sposób swojego wizerunku. Dlatego na co dzień, pozostając we własnej przestrzeni mieszkalnej, nie korzystają z protez, które traktują jako dodatkowy balast dla ciała. O ile sama estetyka protezy spełniała swoją funkcję, to w przypadku żadnego z badanych proteza nie spełniła związanych z jej używaniem oczekiwań sprawnościowych. W ocenie chorych protezy są niewygodne, ciężkie, uwierające, a przez to całkowicie nieużyteczne. Wyposażeni w nie czują się bardziej niepełnosprawni fizycznie, niż są w rzeczywistości. Poza tym fakt założenia protezy potwierdza niepełnosprawność badanych, każąc im przyznać się do niej tożsamościowo przed samym sobą. Tymczasem, badani dzielili się swoimi odczuciami związanymi z nigdy nie podjętymi bądź podjętymi z dużym oporem i niechęcią staraniami o orzeczenie w ich przypadku stopnia niepełnosprawności związanego z posiadanym deficytem cielesnym. Stała za tym poważna obawa przed sklasyfikowaniem każdego z tych respondentów jako osoby niepełnosprawnej. Uzyskanie takiego orzeczenia byłoby równoznaczne $\mathrm{z}$ tym, że musieliby się z nim zgodzić i za niepełnosprawnych się uznać. Badani natomiast nade wszystko właśnie sami przed sobą nie chcą uznać swojej niepełnosprawności, a niechęci tej dowodzi ich zaangażowanie w procedurę kwalifikacji do transplantacji kończyny.

\subsubsection{Możliwości i ograniczenia sfragmentaryzowanego ciała}

Kolejny motyw transplantacyjny respondentów, zawierający odwołanie do ich sytuacji biograficznej, każe przyjrzeć się ich działaniu w rzeczywistości życia codziennego, gdyż to ono jest fundamentem wszelkich doświadczeń cielesnych. $\mathrm{O}$ ile badani nie zaakceptowali dotąd swojego ciała w jego wymiarze estetyczno-wizerunkowym, to z pewnością w pewnej mierze udało im się pokonać jego kolejne ograniczenia sprawnościowe. Mimo początkowych problemów z ruchową 
adaptacją do nowej formy ciała, chorzy z jednostronnym deficytem kończyny z czasem nauczyli się takich czynności jak samodzielne przygotowywanie posiłku, mycie włosów i twarzy czy ubieranie się. Czas, jaki upłynął od amputacji, pozwolił im rozpoznać nie tylko ograniczenia własnego ciała, ale i jego możliwości:

Ja od pierwszych dni, jak tylko wrócitem ze szpitala po amputacji zaczqłem przełamywać te wszystkie bariery, zaczałem sprawdzać, co potrafię. Od samego poczatku miałem to w głowie, że muszę uczyć się żyć bez tej ręki. Te problemy, które najbardziej mi doskwierały, to od razu zaczałem je przełamywać. Już teraz to potrafię sobie coś ugotować, ubrać się i umyć całkowicie. (mężczyzna, 40 lat)

Bardzo dobrze sobie radze w gotowaniu, krojenie, siekanie, to wszystko mam opanowane. Nie potrzebuje tutaj drugiej osoby do tego. Umyję się też jednq ręka, absolutnie nie mam z tym problemu. Z ubieraniem też sobie radzę, nawet z guzikami. Wszystko daję radę zrobić oprócz wiqzania butów, bo tu siła rzeczy nie da się. (mężczyzna, 41 lat)

Ciało objawia się badanym natomiast jako kłopotliwe w sytuacjach nowych, które wiążą się z koniecznością działania dotychczas niewykonywanego. Tutaj w doświadczanie własnej cielesności wkrada się lęk i niepewność, które potęguje konieczność pomocy ze strony innych ludzi. Tymczasem badani nie chcą i nie lubią z niej korzystać. Odwołanie się do pomocy innych traktują jako przyznanie się do własnej słabości. Mimo napotykanych kolejnych barier jakie stwarza im okaleczone ciało, starają się w możliwie najszerszym zakresie pozostać samodzielni. Irytują się, jeśli ktoś próbuje wyręczyć ich z wykonania określonej czynności. Określa ich silna determinacja i upór w walce z trudnościami, na jakie napotykają w życiu codziennym. Zdecydowanie odrzucają postawę wycofania czy rezygnacji. Za wszelką cenę dążą do podtrzymywania aktywności życiowej:

Nie chcę być na czyjejś prośbie, czy łasce, niezależnie jak to nazwiemy. Ja chcę pracować, być aktywny. Ale jak zdarzy się jakaś awaria sprzętu w pracy, jakiejś maszyny, to wtedy dzwonię po kogoś, bo sam sobie nie poradzę. Nie chce jednak tego robić zbyt często, bo nie chcę, żeby mnie brali za niepetnosprawnego. Dlatego ja nie chciatem iść na rente, ja chciałem wrócić do pracy. I naprawde, wiem, że to zabrzmi dziwnie, ale dobrze sobie radzę bez tej ręki. (mężczyzna, 40 lat)

Także badani z dwustronnym deficytem kończyny przyznają, że choć w niewielkim stopniu, to jednak udało im się zastąpić pracę rąk działaniem innych części ciała (np. ust i stóp) przy wykonywaniu takich czynności jak na przykład jedzenie, gotowanie, sprzątanie czy obsługa komputera. Niektórzy wyrażają nawet zadowolenie $\mathrm{z}$ osiagniętego poziomu użyteczności ciała, mimo jego sfragmentaryzowania. W przypadku tej grupy badanych istnieją jednak takie czynności, w realizacji których bariera jaką stwarza niekompletne ciało, wydaje się nie do pokonania. I tak, największą trudność sprawiają tym chorym czynności skierowane na własne ciało, w których całkowicie zostają zdani na pomoc członków rodziny. To właśnie działania związane z realizacją potrzeb fizjologicznych i higieną intymną są tymi, w których badani najdotkliwiej odczuwają brak kończyn. 
Zwłaszcza, że u niektórych z nich deficyt kończyn górnych współwystępuje $\mathrm{z}$ deficytem kończyny dolnej:

Budzę się późno, około jedenastej. I czuję, że chce mi się „siku”. I uświadamiam sobie, że mama przyjdzie późno. I to jest straszne, bo siedzę i nie mogę nic zrobić. I wtedy najbardziej się denerwuję. Najczęściej wtedy czuje taka bezradność. Nawet jak spotykam się ze znajomymi, to wiem, że mogę być z nimi tylko dwie godziny, bo potem jak okaże się, że muszę skorzystać z toalety, to musiałabym prosić o pomoc inne osoby. I może one nie miałyby nic przeciwko temu, ale to jest takie wchodzenie w moja intymność, które jest dla mnie najgorsze. (kobieta, 22 lata)

Posiadane ograniczenia funkcjonalne ciała w ewidentny sposób zaważyły na poczuciu męskości respondentów tej kategorii płci. Badani mężczyźni nie przypisują swojemu ciału w jego sfragmentaryzowanej formie żadnej wartości. Ocena ta dokonywana jest przede wszystkim z perspektywy jego użyteczności. A ta mierzona jest na przykład umiejętnością prowadzenia samochodu, w której badani nie czują się pewni możliwości swojego ciała. Pozbawieni kończyn(y) mężczyźni czują się też bezbronni. Świadomość tego, że w obecnej formie ciała nie byliby w stanie fizycznie obronić się w sytuacji zagrożenia godzi w ich męską tożsamość:

Nie mam rąk, więc ja się $w$ żadnej sytuacji nie jestem $w$ stanie obronić, nie obronię swojej żony. Poza tym lubię samochody, kocham wręcz samochody i bardzo mi brakuje tego, żeby poprowadzić samochód, żeby chociaż mieć namiastkę tego, co było kiedyś. Gdybym sam mógt gdzieś pojechać... To już by było bardzo dużo, żeby czuć sięjak mężczyzna. (mężczyzna, 40 lat)

Opis doświadczania deficytu kończyn(y) nie byłby pełny, jeśliby pominąć dostrzegalny $\mathrm{w}$ narracji badanych wątek tęsknoty za utraconymi częściami ciała, której przejawem, zgodnie z interpretacją fenomenologiczna, mają być stany urojonej kończyny. Badani, którzy utracili rękę wskutek urazu tęsknią za odczuciami, jakie dawało im posiadanie obu rąk. Mowa tutaj zwłaszcza o doznaniach związanych z używaniem rąk w działaniu. „Posiadanie urojonej kończyny znaczy tyle samo, co bycie otwartym na działanie, na kompletny świat, który chorego otacza. W myśl interpretacji fenomenologicznych zespół urojonej kończyny polega na tym, że chory z amputowaną kończyną postrzega przedmioty jako użyteczne, mimo że nie może już nimi manipulować" (K ow al 2014: 97). Traktują o tym poniższe wypowiedzi badanych, w których tak opisują działania podejmowane przez utraconą kończynę:

Ja czuję te ręce cały czas, że mam dłonie. Ja... o... ruszam nimi [tu badana demonstruje ruch kikutami - przyp. badaczki]. Jak coś chce zrobić, to chwytam tymi rękami, no a przecież wiadomo, że wszystko z rąk leci, bo rąk nie ma. (kobieta, 55 lat)

Tak to czuję, powiem pani, że jak coś robię, to próbuję sobie ta rękq trochę pomóc. I wtedy te palce się tak wykrzywiaja, bo jak ja używam tej ręki, to boli. Dlatego nie używam zbyt często tej ręki. Muszę przestać myśleć, że coś muszę zrobić ta rękq. Do tyłu chowam tę rękę, żeby sobie nią nie pomagać. (mężczyzna, 36 lat) 
Analiza opisywanych przez badanych działań nawykowych podejmowanych fantomową kończyna, ekspresji jej ruchów, sięgania po przedmioty znajdujące się w ich przestrzeni życia, każe potraktować doświadczanie urojonej kończyny jako przejaw negacji kalectwa i związanych z nim ograniczeń. Zgodnie z fenomenologiczną perspektywą „bycia w świecie”, „tym co w nas odrzuca kalectwo i chorobę, jest Ja zaangażowane w pewien fizyczny i międzyludzki świat, które nadal wytęża siły, odnosząc się do swojego świata wbrew słabościom i amputacjom, i które właśnie dlatego «de iure» ich nie uznaje" (Merleau-Ponty 2001: 99-100).

\subsection{Transplantacyjne motywy ,żeby"}

O ile wyjawienie motywów typu ,ponieważ” będących motywami przyczynowymi, mimo ich zdecydowanie obiektywnego charakteru, było możliwe dzięki wnikliwym analizom materiału empirycznego, subiektywnych motywów typu ,żeby” badani byli świadomi, a zapytani wyjawiali ich znaczenie w badaniu. Według A. S c h ütza motyw ,żeby” (in-order-to motive) ${ }^{6}$ oznacza „stan rzeczy czy też cel, który ma być osiagnięty poprzez podjęte działanie" (2012: 133). Skupię się zatem teraz na tych motywach potencjalnych biorców kończyny, które skłaniają ich do poddania się zabiegowi transplantacyjnemu w kontekście przyszłościowym.

\subsubsection{Rekonstrukcja sprawności ciała}

Głównym motywem skłaniającym respondentów do poddania się przeszczepieniu kończyny jest chęć uzyskania większej sprawności własnego ciała, która ma pozwolić na realizację opisanych poniżej konkretnych i uprzednio także przemyślanych celów szczegółowych. W związku z potencjalną odbudową sprawności cielesnej w wyniku transplantacji badani oczekują nade wszystko zmiany jakościowej w życiu codziennym, w tym przede wszystkim w sferze pracy zawodowej. Choć niektórzy respondenci podtrzymują aktywność zawodową, to twierdzą, że obecne zajęcie nie tylko nie daje im satysfakcji, ale też nie pozwala w żaden sposób spożytkować drzemiącego w nich potencjału. Z racji na posiadane ograniczenia ciała nie mogą bowiem awansować z zajmowanych od wielu lat stanowisk. Chorzy, którzy utracili kończynę wskutek urazu mechanicznego, chcieliby wrócić do wykonywania pracy zawodowej sprzed wypadku. Posiadany deficyt ciała, póki co, jednoznacznie ich z tego dyskwalifikuje:

Nie mam rak $i$ bez rak na pewno nie będę awansowat. Ja uważam tę pracę, która mam, że to jest taka... Jest, bo jest, bo do tego się moi pracodawcy zobowiazali, ale ja nie widzę żadnych

${ }^{6} \mathrm{~W}$ pracach A. S c h ü t z a ten typ motywów występuje w dwóch nieznacznie się różniących, synonimicznych przekładach językowych jako motywy ,żeby” (2006) i motywy ,ażeby” (2012). W swojej pracy polegać będę konsekwentnie na pierwszym brzmieniu tego spójnika. 
możliwości rozwoju w tej pracy, zmiany stanowiska na wyższe. Liczę na to, że jak już będę miat te ręce przeszczepione, to wrócę do dawnej pracy, może nawet pójdę na studia. (mężczyzna, 40 lat)

Dzięki zyskaniu większej sprawności ciała badani chcą usamodzielnić się w codziennym funkcjonowaniu, co oznaczałoby na przykład odzyskanie umiejętności pełnej samoobsługi higienicznej czy większą mobilność, którą mógłby badanym zagwarantować powrót do czynności prowadzenia samochodu. Potencjalni biorcy kończyn(y) chcieliby w rezultacie poddania się przeszczepieniu uzyskać taką sprawność ciała, która pozwoliłaby im nie tylko całkowicie uniezależnić się od pomocy innych ludzi, ale także poczuć się bardziej dla nich potrzebnymi. Chodziłoby tu o łatwiejsze wypełnianie przez badanych roli rodziców i związanych z nimi czynności opiekuńczych nad potomstwem. W przypadku jednej $\mathrm{z}$ badanych kobiet sam fakt urodzenia dziecka stanowił wystarczającą motywację, by przystąpić do procedury kwalifikacji do zabiegu transplantacji kończyny. Poczucie odpowiedzialności za swoje rodziny nie pozwala badanym pozostawać biernymi wobec własnej dysfunkcji cielesnej:

Jak urodziłam córkę, to już wiedziałam, że teraz to jest ten moment, żeby jechać do Trzebnicy i poddać się badaniom. Bo ja na początku w ogóle bałam się brać mojej matej do siebie, na kolana. No bo bałam się, że ja upuszczę. I wtedy właśnie sobie postanowiłam, że muszę mieć te ręce, żeby w ogóle móc zajać się swoim dzieckiem. Wiem, że nawet jeśli będę miała tylko jedna sprawnq rękę, to będzie mi łatwiej. (kobieta, 33 lata)

To, co jeszcze określa sytuacje biograficzne badanych, to posiadane jeszcze przed amputacją kończyn(y) liczne pasje życiowe, tak silnie związane ze zdolnościami manualnymi jak choćby modelarstwo, lotnictwo, rysowanie, kreatywne rękodzieło (cardmaking, wytwarzanie biżuterii z włóczki), gra na instrumencie, pielęgnacja ogrodu czy też po prostu wymagające kooperacji rękami jak motoryzacja, strzelectwo i taniec. Powrót do ich realizacji okazuje się ważnym transplantacyjnym motywem „żeby”. Dlatego oczekiwania dotyczące sprawności przeszczepionej kończyny są przez respondentów bardzo precyzyjnie określone. Mam tutaj na uwadze procentowane określenie ruchomości palców i dłoni w przeszczepionej kończynie, które najpierw miałoby pozwolić badanym na realizację takich czynności jak zapinanie guzików koszuli, sznurowanie butów czy wybranie numeru na klawiaturze telefonu komórkowego. Już sama realizacja tych prozaicznych, codziennych czynności, traktowana przez respondentów jako zapowiedź wyższych możliwości manualnych, oznaczać będzie dla biorców przeszczepu kończyny udaną transplantację:

Ja to oczekuję tylko tej sprawności większej, nie mówię, że stuprocentowej, ale tak osiemdziesiat, dziewięćdziesiat procent, żeby była. Do tych guzików, do tych koszul, do włożenia butów. Jakbym to umiał zrobić, jakbym to wszystko miat, to by byt już sukces, by bym mógt już wszystko robić, co lubiłem kiedyś. (mężczyzna, 36 lat)

W polu widzenia potencjalnych biorców znajduje się też motyw transplantacyjny związany z funkcjami sensorycznymi przeszczepu. Badani oczekują, że przeszczepioną kończyną będą mogli odbierać wrażenia czuciowe. I tak na 
przykład niektórzy z nich marzą o tym, aby po przeprowadzonej transplantacji móc dotknąć przeszczepioną kończyną ręki innego człowieka, poczuć jej uścisk w geście powitalnym. To, co badani chcieliby zatem osiagnąć przez transplantacyjną rekonstrukcję ich ciał dotyczy nie tylko sfery ich fizycznego funkcjonowania, ale i kontaktów społecznych. Oczekiwania związane z wrażliwością czuciową przeszczepu nie mogą być jednak podzielane przez tych chorych, u których deficyt kończyny ma charakter wrodzony. I tak, jedna z chorych, która żyje z wrodzoną wadą braku kończyny w trakcie procesu kwalifikacji do zabiegu transplantacyjnego dowiedziała się, że przeszczepiona jej ręka w stopniu wysoce prawdopodobnym pozbawiona będzie czucia. Mimo takich rokowań, nadal deklaruje chęć skorzystania z tej metody leczenia i podtrzymuje swoją aktywność w procesie kwalifikacyjnym:

Pan doktor powiedziat mi, że nie będe ta ręka nic mogła poczuć, że ja ja po prostu tylko będę miata, mniej czy bardziej sprawnq. Ale ja się fizycznie poczuję pewniej, jak będęuż tylko mieć te ręke, nawet tylko troche sprawna. (kobieta, 18 lat)

Chorzy okaleczeni nie tylko brakiem rąk, ale posiadający jeszcze deficyty w obrębie kończyn dolnych oczekują, że wyższa sprawność ciała po transplantacji kończyny górnej pozwoli im lepiej radzić sobie z własną niepełnosprawnością ruchową. Chodzi tutaj o to, aby poprzez przeszczepienie kończyn górnych uczynić ciało bardziej użytecznym w radzeniu sobie z jego innymi deficytami:

Nie umiem sobie sama założyć protezy nogi. Liczę na to, że ten przeszczep ręki mi pomoże w tym. Najbardziej chodzi mi właśnie o tę protezę nogi, żeby móc sobie ja założyć sama i móc wyjść nareszcie z domu. W tej chwili nie moge wyjść na dwór, bo przejdę na tej jednej noce skaczac co najwyżej pięć metrów i się przewracam. Ubranie protezy nogi sprawia mi w tej chwili największy problem, no bo jak mam zapiać te wszystkie pasy, jak ja nie mam rak. (kobieta, 33 lata)

Kwestia sprawności ciała, która u badanych z obustronnym deficytem rąk jest szczególnie mocno eksponowana jako motyw transplantacyjny, dotyczy także bardziej odległej perspektywy czasowej. Badanym, którzy formułowali takie motywy towarzyszył bowiem lęk przed starością i związaną z nią niepełnosprawnością ciała, która w ich przypadku byłaby dodatkowo pogłębiona przez brak kończyn.

Mimo zasadniczej nieakceptacji swojego okaleczonego ciała, wraz z podjęciem decyzji o poddaniu się transplantacji kończyny, badani zaczynają poświęcać mu czas i uwagę. Co jednak istotne, dotyczy to zwłaszcza tych jego części, od sprawności których zależeć będzie jak najlepsze funkcjonowanie potencjalnego przeszczepu. Przyszli biorcy kończyny górnej prowadzą zatem własne przygotowania do zabiegu, które polegają na ćwiczeniach mięśni naramiennych i usprawnianiu kikuta celem podtrzymywania jego ruchomości. Wszystkie te starania mają przybliżyć badanych do osiagnięcia założonego przez siebie celu odzyskania sprawnego ciała. Przyznają oni jednak otwarcie, że nie angażowaliby się 
w usprawnianie swojego niekompletnego ciała gdyby nie perspektywa zabiegu transplantacyjnego. Ta ostatnia sprawia, że rezygnują ze starań o zakup nowoczesnej protezy.

Uzyskanie wyższej sprawności ciała jest warunkiem akceptacji ciała w jego zrekonstruowanej formie. Potencjalni biorcy rozważali także w trakcie wywiadu hipotetyczną sytuację, w której następstwem przeszczepienia będzie nie wyższa, a niższa sprawność zrekonstruowanego ciała. Zgodnie z treścią zebranego tu materiału empirycznego, nawet jeśliby przeszczepiona ręka miała u badanych spełniać wyłącznie funkcję estetyczną, chcą poddać się transplantacji. Samo posiadanie ręki, jej obecność, mogłaby okazać się dla nich wystarczającym motywem „żeby”.

\subsubsection{Estetyczny obraz wlasnego ciala}

Estetyka wizerunkowa ciała zajmuje w transplantacyjnej motywacji potencjalnych biorców kończyny znaczące miejsce, choć trzeba wyraźnie zastrzec, że pozostaje kwestią relatywnie mniej ważną niż wynik sprawnościowy planowanej rekonstrukcji ciał badanych. Sensem estetycznej motywacji potencjalnego biorcy kończyny jest wyobrażenie sobie swojego ciała po transplantacji, co dzieje się zanim zaprojektowane zostaną przez niego kolejne kroki związane z udziałem w tym zabiegu, które mają doprowadzić do tego właśnie wyobrażonego obrazu i formy ciała. A. S c h üt z twierdzi, że „czyn, który zostanie zrealizowany, stanowi punkt wyjściowy naszego projektowania" (2012: 132). Biorca musi zobaczyć w wyobraźni swoje zrekonstruowane ciało, czyli musi zmaterializować wyobrażeniowo efekt transplantacji. $Z$ pewnością łatwiej jest kandydatowi na biorcę wyobrazić sobie swój udział w przeszczepieniu, aniżeli jego efekt w postaci ciała zrekonstruowanego przez przeszczep ręki pobranej od obcego człowieka. Zgodnie jednak z fenomenologicznym ujęciem struktury czasowej projektu, nie o przyszłe działanie tu chodzi, a o ,przyszyły czyn wyrażony w czasie przyszłym dokonanym" (modo futuri exacti) (S c hü tz 2012: 132). Chory nie wie, jak będzie wyglądać jego „nowa” ręka i nie może dowiedzieć się tego na etapie rozważania decyzji o poddaniu się przeszczepieniu. Musi włożyć pewien wysiłek w wyobrażenie sobie obrazu swojego ciała po transplantacji. I to właśnie ten wyobrażony obraz estetycznego, dzięki swojej kompletności, ciała jako stan rzeczy, do którego ma prowadzić przyszłe działanie biorcy, jest motywem ,żeby” tego działania. Wyobrażenie sobie przez badanych własnego ciała uzupełnionego o brakującą kończynę musi nastapić, aby chory zaplanował kroki swojego przyszłego działania, mające prowadzić w finale tego projektu do przeszczepienia.

Estetyczne motywy poddania się zabiegowi transplantacji kończyny górnej dotyczą ściśle pochodzenia i wyglądu samego przeszczepu. Wspólną cechą zgłaszanych w tym względzie wyidealizowanych przez respondentów oczekiwań jest to, aby potencjalna kończyna była jak najbardziej zbliżona wyglądem do utraconej biologicznej ręki chorego. Niektórzy z badanych używali nawet tutaj określenia 
„identyczna”, przy zachowaniu świadomości nieuzasadnionego charakteru tychże oczekiwań. Znamienne są tutaj używane przez badanych sformułowania typu „chcę odzyskać swoją rękę". Badanym zależy przede wszystkim na anatomicznym dopasowaniu przeszczepu do ciała, w taki sposób, aby jego obraz nie został zniekształcony. W istocie, transplantolodzy w doborze dawcy i biorcy zmuszeni są uwzględniać nie tylko ich kryteria immunologiczne, ale także podobieństwa w zakresie parametrów anatomicznych i estetycznych. Co się tyczy cech wyglądu zewnętrznego przeszczepionej choremu ręki, to staraniem lekarzy jest, aby możliwie odpowiadała ona wymiarowi, budowie i układowi kostnemu biologicznej kończyny potencjalnego biorcy (J a błe cki, C h ełm oń s ki 2011: 52). Jednym $\mathrm{z}$ najistotniejszych warunków zawartych $\mathrm{w}$ oczekiwaniach badanych chorych jest wiek potencjalnego dawcy kończyn(y), który zgodnie z ich uzasadnieniem rzutuje przede wszystkim na kwestie wizerunkowe ciała. Za przykład takich oczekiwań ich posłużą poniższe wypowiedzi badanych:

To nie jest tak, że kwestie estetyczne sq tutaj w ogóle nie ważne, choć tak jak mówię, one sq na drugim planie. Ale nie chciałabym otrzymać ręki za dużej, z którq nie mogłabym sobie poradzić. Żeby ta ręka była proporcjonalna do mojego ciała, no i przede wszystkim, żeby była od młodej osoby, w moim wieku, a płeć nie jest ważna. Tak, żeby nie była jakaś pomarszczona, szara, z jakimiś starczymi plamami, żeby to nie wygladało jakoś nieestetycznie. (kobieta, 22 lata)

Martwię się, żeby te ręce nie byly zbyt duże, bo jak będa takie wielkie tapska, to co ja z nimi zrobię? One już przecież nie schudnq. U mnie pteć nie ma znaczenia. Niech to będzie ręka od mężczyzny, ale mówię - od młodego mężczyzny. Bo taki młody chtopak nie będzie miat wielkich tap, a starszy to wiadomo, już ma większe. Ja w ogóle chcę ręce od młodej osoby, bo ja mam ciało jędrne, dbam o nie, nie mam zmarszczek, więc takie ręce tylko będa mi pasowaty. (kobieta, 55 lat)

Jeśliby zatem warunek estetycznego dopasowania został spełniony, dla badanych kobiet nie miałoby znaczenia to, że przeszczepiona ręka pochodzi od dawcy płci męskiej. Przeszczep kończyny pobranej od mężczyzny w ogóle był bardziej preferowany przez badanych. Bez względu na ich własną płeć, respondenci chcą otrzymać przeszczep ręki pochodzący od mężczyzny, co w ich opinii miałoby się przekładać na jej lepszą witalność, wyższą sprawność, a co za tym idzie estetyczny obraz ciała. Idealnym typem dawcy kończyn(y) miałby być dla badanych młody, silny mężczyzna, którego cechy biologiczne pozwoliłyby im, zgodnie z formułowanymi oczekiwaniami, eksploatować przeszczepioną rękę w takim stopniu, jak niegdyś własną kończynę:

Wolałbym męska rękę, bo taka bardziej rokuje w sensie sprawności. Moim zdaniem taka ręka byłaby silniejsza. A mi zależy na sprawności, ale na wygladzie też. A wiadomo, że jak ręka nie będzie sprawna, to będzie tylko zwisać bezwiednie i to nie będzie dobrze wygladato. (mężczyzna, 40 lat)

Chciałabym rękę od młodej osoby, bo taka będzie i tadniejsza i sprawniejsza. Nie zależy mi na tym, żebym dostała rękę od kobiety, bo myślę, że jeżeli dostane rękę od mężczyzny, to będzie 
silniejsza. Nie chodzi mi o to, żeby jakieś muskuty miała, tylko chodzi o to, że szybciej załapie tę sprawność, jaka miata moja ręka. (kobieta, 22 lata)

Z sensu sformułowanych powyżej oczekiwań można wywnioskować, że badani chcieliby dzięki transplantacji uzyskać ciało, którego wizerunek nie będzie zdradzał ani faktu jego transplantacyjnej rekonstrukcji, ani uprzedniego sfragmentaryzowania. Po przeprowadzonym przeszczepieniu kończyn(y) badani chcą dobrze wyglądać i czuć się we własnym ciele. Co równie dla nich ważne, przywrócenie ciału estetycznego wyglądu ma zapewnić im lepszy wizerunkowy odbiór w przestrzeni społecznej. Dlatego najważniejsze obawy, które badani wiązali z zabiegiem transplantacyjnym, dotyczą potencjalnego odrzucenia przeszczepu bądź wystąpienia powikłań pooperacyjnych wymuszających amputację przeszczepu. Potencjalnym biorcom towarzyszy strach przed tym, że mogliby utracić rękę po raz drugi i po raz drugi doświadczyć niekompletności ciała.

\subsection{Fenomenologiczne ujęcie decyzji o poddaniu się transplantacji kończyny górnej}

Decyzja o poddaniu się transplantacji kończyny górnej w przypadku każdego z badanych potencjalnych biorców jest samodzielna. Co ważne jednak, nie zawsze spotyka się ona z empatyczną postawą członków rodziny chorego. Niektórzy z respondentów nie doświadczyli w tym względzie oczekiwanego wsparcia ze strony bliskich im osób. W ich otoczeniu społecznym znalazły się osoby, które nie tylko nie zachęcały, ale wprost odradzały im skorzystanie z tej metody leczenia. W argumentacji tychże osób zabieg transplantacji postrzegany jest jako niepotrzebne narażenie chorego na cierpienie związane z samym zabiegiem operacyjnym i późniejszą rehabilitacją oraz ryzyko wystapienia powikłań na skutek przyjmowania leków immunosupresyjnych. Biorąc pod uwagę to ostatnie, pojawia się argument o nieracjonalności decyzji chorego. Z całkowitym niezrozumieniem wymienionych osób spotkały się opisane powyżej motywy chorych, a ich działanie nakierowane na poddanie się przeszczepieniu kończyny zostało uznane za odbiegające od typowego zachowania czy sposobu radzenia sobie w sytuacji okaleczenia deficytem kończyn(y). W potocznym wyobrażeniu środki, po które sięgają chorzy, zostały uznane przeze te osoby za odbiegające od społecznie aprobowanych reguł radzenia sobie $\mathrm{z}$ tego typu sytuacjami (mowa o protezowaniu ciała), a sama metoda przeszczepienia ręki została określona jako eksperymentalna i przez to budzącą wątpliwości co do efektu przeszczepienia.

„Racjonalne działanie - według A. S c h üt za - zakłada, że aktor ma jasny i wyraźny wgląd w cele, środki i uboczne skutki swego działania" (2006: 881882). Spełnienie tych warunków jest sednem standardowej procedury kwalifikacji chorego na biorcę kończyny górnej. Chorzy oczekujący na transplantację kończyny są uświadamiani w procesie kwalifikacji do zabiegu co do samej jego istoty, następstw i ewentualnych powikłań. Otrzymują szczegółową informację o tym, 
jak przebiega leczenie immunosupresyjne i jakie są jego skutki uboczne. Rolą lekarzy prowadzących chorych w procesie kwalifikacji do zabiegu transplantacji ręki jest też poinformowanie kandydata o możliwym do uzyskania $\mathrm{w}$ indywidualnym przypadku każdego z chorych efekcie funkcjonalnym przeszczepu i związanych z tym rokowaniach. Rzetelna informacja na ten temat, pochodząca od profesjonalistów medycznych, ma zapobiec formułowaniu przez pacjentów nierealistycznych oczekiwań dotyczących rezultatów przeszczepienia (Jabłecki, Chełm oń s ki 2011: 53). Kandydat na biorcę w trakcie trwania procedury kwalifikacyjnej racjonalnie rozważa różne środki, które mogą go doprowadzić do realizacji celów związanych z odzyskaniem kompletnej formy ciała. Na tym etapie chory dowiaduje się o możliwościach pozostających w jego zasięgu protez kończyny oraz przedstawiona zostaje mu metoda rekonstrukcji jego ciała za pomoca przeszczepu kończyny pochodzącego od zmarłego dawcy. Podejmuje też wysiłek udzielenia sobie odpowiedzi na pytanie, na ile rezultaty zastosowania każdego z tych dwóch środków pozwolą mu na realizację upragnionych celów. I w końcu chory musi dokonać analizy samych celów, starając się ocenić ich ważność. W przedstawionych warunkach nie sposób nie dostrzec cech racjonalnego działania Maxa Webera, z którego wyłączone muszą być jakiekolwiek działania motywowane emocjami (We ber 1947: 117). W istocie, sensem oceny kandydata na biorcę kończyny w jej części psychospołecznej jest wykluczenie z procedury tych chorych, których decyzja o poddaniu się przeszczepieniu miałaby stricte emocjonalny charakter.

Skoro ocena działań biorcy z punktu widzenia ich (nie)racjonalności jest różna u aktora działania (biorcy) i obserwatorów (członków rodziny), wypada poświęcić nieco miejsca na fenomenologiczne wyjaśnienie tego stanu rzeczy. Za punkt wyjścia należy przyjąć różny zasób wiedzy, który posiada aktor i obserwator. „Nawet generalna teza przekładalności perspektyw nie wystarcza do wyeliminowania tych trudności, ponieważ zakłada, że do realizacji praktycznych celów systemy istotności obserwatora i obserwowanego są wystarczająco homogeniczne w strukturze i treści” (S c h üt z 2006: 882). W sytuacji tych badanych, którzy nie znajdują wsparcia wśród członków rodziny dla swojego projektu transplantacyjnego, najwyraźniej owe systemy istotności nie są jednorodne. Poddanie się transplantacji ręki przez samych chorych jest oceniane jako wysoce racjonalne, podczas gdy ich bliscy uznają je za pozbawione racjonalności. Szczególnie trudna do przyjęcia przez niektórych badanych była sytuacja nierozumienia ich decyzji przez współmałżonka czy partnera życiowego bądź rodziców. „Aktor może zakładać, iż to, co on przyjmuje za oczywistość, jest oczywiste również dla «każdego, kto jest jednym z nas», ale to, czy założenie to ma zastosowanie do konkretnego bliźniego zależy od faktu uprzedniego ustanowienia pomiędzy nimi autentycznej relacji «my»" (S c h üt z 2012: 152). Mimo że warunek ten, w przypadku wymienionych osób, był spełniony, sama relacja „my” między biorcą a obserwatorem była w tym przypadku niewystarczająca. 
Przyczyn empatycznego niezrozumienia przez bliskie osoby intencji potencjalnego biorcy należy też szukać $\mathrm{w}$ różnicach związanych $\mathrm{z}$,biograficznie zdeterminowaną sytuacją oraz dokonywaną w jej obrębie selekcją istotnych elementów" (S chütz 2012: 152). Brak przekonania bądź wyrażona stanowcza dezaprobata członków rodziny chorego wobec zamiaru poddania się przez niego transplantacji kończyny wynika z braku wskazań życiowych do jego przeprowadzenia. A skoro nie jest to zabieg ratujący życie, a wyłącznie podnoszący jego jakość, w bilansie potencjalnych korzyści i kosztów związanych z tą metodą leczenia mają przeważać te drugie. Czy jednak członkowie rodziny chorego okaleczonego deficytem kończyny, nawet jeśli pozostają bezpośrednimi obserwatorami jego zmagań z ograniczeniami dyktowanymi przez niekompletne ciało i nawet jeśli znają motywy skłaniające go do poddania się zabiegowi transplantacyjnemu, są w stanie zrozumieć potencjalnego biorcę w pełni? Fenomenologicznie rzecz ujmując jest to niemożliwe, mimo że opisane powyżej motywy ,ponieważ” stanowią ,kategorię obiektywną, która dostępna jest obserwatorowi” (S c h ü t z 2012: 134). Członkowie rodziny badanych nie uczestniczą bezpośrednio w rozstrzyganiu tego, w jakim ciele biorca chce dalej żyć. Nie uczestniczą też bezpośrednio w samym akcie podejmowania przez chorego decyzji o przeszczepieniu. Staraniem zespołu przygotowującego chorego do objęcia go omawianą metodą leczenia rekonstrukcyjnego jest, aby decyzja potencjalnego biorcy była nie tylko świadoma, ale i samodzielna. W jednej z prac transplantologów wchodzących w jego skład czytamy: „Tylko głęboko umotywowani pacjenci wyrażający aktywnie wolę transplantacji ręki mogą być akceptowani. Jest niezwykle istotne pozostawienie pacjentowi czasu do własnej oceny korzyści wynikających z przewidywanej po zabiegu poprawy jakości życia wobec wszelkich zagrożeń związanych z transplantacją" (Jabłecki, Chełmoński 2011: 53). Ujmując rzecz fenomenologicznie, zaprojektowane przez biorcę działanie na etapie podjęcia o nim decyzji nie zakłada włączenia weń działania innych osób. Wsparcie członków rodziny, które oznacza już konkretną reakcję bliskich, a być może i jakieś działania, potrzebne są choremu natomiast już po podjęciu decyzji o poddaniu się transplantacji, a więc przez cały okres kwalifikacji do przeszczepienia i oczekiwania na wezwanie do jego przeprowadzenia. Potwierdzają to te oto słowa lekarzy uczestniczących w procedurze kwalifikacji biorców kończyny górnej: „Ważnym czynnikiem wpływającym na stan psychiczny biorcy jest wspierająca postawa najbliższego otoczenia, zarówno $\mathrm{w}$ okresie przygotowania do zabiegu, jak i w okresie pooperacyjnym" (C h eł m o ń s k i, J a błe c k i 2011: 44). A tak formułuje ten warunek A. S chütz: „musi istnieć wystarczające prawdopodobieństwo, że inny dostroi się do mnie i będzie uważał moje działanie za na tyle istotne, by był motywowany w sposób «ponieważ» przez mój motyw «ażeby»" (2006: 884). A zatem, bez względu na wcześniejsze stanowisko członków rodziny do transplantacyjnej inicjatywy chorego, kiedy zapadnie decyzja o poddaniu się temu zabiegowi, bliscy chorego powinni starać się ją zrozumieć. „W wypadku racjonalnej 
interakcji znaczy to, że [inny] będzie interpretował moje działania racjonalnie jako racjonalne i będzie reagował na nie w racjonalny sposób" (S c hü tz 2006: 884). Aby tak się stało $\mathrm{w}$ odniesieniu do omawianego problemu, członkowie rodziny chorego mający okazywać mu wsparcie w transplantacyjnym projekcie muszą mieć o nim wystarczającą wiedzę, muszą wiedzieć, jak ważny jest dla biorcy ten projekt spośród wszystkich jego planów oraz muszą znać jego „system istotności” (S c hüt z 2006: 884). Sama wiedza o zabiegu transplantacji kończyny, któremu biorca ma być poddany powinna obejmować następujące aspekty. Po pierwsze, informację o pochodzeniu przeszczepu, którego dawcą będzie anonimowa zmarła osoba. Po drugie, informację o dającym się przewidzieć, możliwym do uzyskania rezultacie transplantacji w wymiarze kontroli ruchu, czucia oraz efektu kosmetycznego przeszczepionej ręki oraz ubocznych skutkach tego zabiegu. Po trzecie wreszcie, informację o środkach, które umożliwią biorcy osiagnnięcie pożądanego efektu przeszczepienia, co należy rozumieć jako reżim immunosupresyjny, rehabilitacyjny i higieniczny po przeprowadzonej rekonstrukcji, ale co ważne, do końca funkcjonowania przeszczepu w ciele biorcy. To jednak nie wszystkie warunki zaistnienia tego wsparcia. Pozostaje jeszcze czynnik zgodności czy podobieństwa przedstawionej wyżej wiedzy u przyszłego biorcy kończyny i jego rodziny oraz choć częściowego pokrywania się ich systemów istotności. Spełnienie wymienionych warunków oznacza, że motywy kandydata na biorcę stają się również motywami jego bliskich. Najpewniej wsparcie dla transplantacyjnego projektu biorcy jest możliwe do uzyskania ze strony osób wspólnie zamieszkujących z chorym, które dzieląc z nim przestrzeń życia mogą być bezpośrednimi obserwatorami i uczestnikami jego sytuacji biograficznej. Wynikająca z tych okoliczności znajomość problemów związanych z doświadczaniem okaleczonego deficytem kończyn(y) ciała pozwala uznać, że inni mają o biorcy wystarczającą wiedzę, co znaczy, że jest ona tak ,jasna i wyraźna”, jaką ma on sam (S c hü tz 2006: 884). Choć należy równocześnie pamiętać, że „biograficznie zdeterminowane sytuacje - moja i mego bliźniego - muszą różnić się, przynajmniej w pewnym stopniu" (Schütz 2006: 872).

Pozostaje jeszcze kwestia braku wsparcia dla decyzji kandydata na biorce ze strony lekarzy, których chory spotyka w trakcie procedury kwalifikacyjnej. Co istotne, dezaprobata dla tej decyzji wyrażana była nie tylko przez lekarzy pierwszego kontaktu, ale także niektórych specjalistów, w tym przede wszystkim chirurgów i ortopedów. W przypadku tych osób o wiele trudniej o empatyczną postawę i zrozumienie biograficznych determinantów decyzji chorego. Żaden z wymienionych lekarzy w trakcie sporadycznych kontaktów z chorym okaleczonym deficytem kończyny, które nierzadko sprowadzają się tylko do pojedynczych konsultacji, nie jest w stanie zapoznać się z całą historią wcześniejszych doświadczeń pacjenta. A przecież ta tworzy posiadany przez potencjalnego biorcę „,zasób wiedzy podręcznej, zasób unikalny, dany jemu i tylko jemu" (S c h ütz 1962: 76-77, za: S c h üt z 2006: 871). Wymienieni lekarze niewiele wiedzą o tym, co 
poprzedziło decyzję o rozpoczęciu transplantacyjnego projektu chorego. Nie znają też i nie mają szansy poznać kontekstu jego działania. Dowiadują się tylko o pewnym fragmencie działania chorego, który został im ujawniony z racji na konieczność konsultacji z tym konkretnym specjalistą. Co najwyżej mogą otrzymać informację na temat kroków działania, które już udało się potencjalnemu biorcy zrealizować. Ale nawet to nie pozwala na zrozumienie powziętego przez chorego działania, gdyż do tego wymagana jest rekonstrukcja jego motywów. Bez watpienia sens działania potencjalnego biorcy jest różny dla niego samego i dla lekarza jako obserwatora tego działania. Jeśli zatem od wyniku konsultacji z tym konkretnym specjalistą ma zależeć przybliżenie chorego do transplantacji, należy dołożyć starań, aby lekarz postarał się zrozumieć sens działań potencjalnego biorcy (zob. S c hütz 2006: 879-880).

Badani dokonali już wyboru projektu swojego działania. Poddali się procedurze kwalifikacji do zabiegu transplantacji ręki, w której zostali zweryfikowani pozytywnie. Zyskali $\mathrm{w}$ ten sposób status kandydata na biorcę przeszczepu kończyn(y), a ich nazwiska zostały umieszczone na Krajowej Liście Oczekujących na Przeszczepienie Narządu. To wszystko jednak nie oznacza ostatecznej realizacji projektu. Jak w każdym projekcie, tak i w tym zawarta jest niepewność. W bycie potencjalnym biorcą kończyny górnej wpisany jest długi czas oczekiwania na transplantację oraz brak gwarancji tego, czy do niej w ogóle dojdzie. Nie wiadomo, ilu z badanych potencjalnych biorców kończyny dostapi rezultatu opisanego procesu zaprojektowanego działania, czyli w ilu przypadkach działanie to będzie dokonane, co oznaczałoby przeprowadzenie zabiegu transplantacyjnego. Poza tym, każdy z badanych ma, jeśliby użyć tu słów Husserla, kontrmożliwość polegającą na rezygnacji z poddania się przeszczepieniu kończyny, co oznaczałoby niewykonanie projektu (za: S c h üt z 2012: 142). A należy podkreślić, że każdy z chorych ma prawo do wycofania się z tej procedury aż do momentu, w którym znajdzie się na stole operacyjnym. Analizując zagadnienie problematycznych i otwartych możliwości w ujęciu Husserla, A. S c h ü t z pisze, że „w procesie podejmowania decyzji [...] «ja» podąża raz za tă, raz za inną możliwością, i w akcie «zajmowania stanowiska» nadaje ważność raz tej, raz innej możliwości” (2012: 141). Chory może bardzo aktywnie uczestniczyć w działaniach zmierzających w stronę przeszczepienia mu kończyny, co należy rozumieć jako poddanie się procedurze kwalifikacyjnej, w wyniku której może otrzymać status kandydata na biorcę, może również prowadzić własne przygotowania do przeszczepienia, co niejako zostaje przypieczętowane decyzją „na tak" wobec transplantacji. Ale przecież nawet po podjęciu tej decyzji, potencjalny biorca co jakiś czas będzie doświadczał zupełnie przeciwstawnych tendencji, które zacznie rozważać i które nawet mogą mu się wydać atrakcyjne (S c hüt z z 2012: 141). W rzeczywistości kandydaci na biorców przyznawali się do wahań między wykonaniem a niewykonaniem projektu. Alternatywną możliwością jest dla badanych pozostanie w obecnej formie ciała, która może być przecież uzupełniana nowoczesnymi 
i coraz bardziej zaawansowanymi technologicznie protezami. Mowa tutaj choćby o bionicznych protezach ręki, które odwzorowują uczucie dotyku. I tak chory ocenia wagę tych możliwości, konfrontuje je z własnymi motywami, które na ogół jedną z nich osłabiają, a drugą wzmacniają.

A. Schütz w analizie teorii woli Leibniza odwołuje się do słów tego ostatniego, który twierdzi, że motywy skłaniaja człowieka do czynu, ale go nie przymuszajq (S c h ü tz 2012: 146; zob. szerzej L e i b n i z 2001). Badani podkreślali kwestię swobody ich wyboru, ale też tylko sobie przypisywali prawo do wiążących rozstrzygnięć w kwestii rozważań za i przeciw poddania się zabiegowi transplantacyjnemu, w czym też pragnęli czuć się wolni. Skoro znane są argumenty za poddaniem się przeszczepieniu kończyny, wypada jeszcze poświęcić nieco miejsca na pojawiające się w rozważaniu tej decyzji obawy i wątpliwości związane z potencjalnym udziałem w nim badanych, mogące jawić się im jako argumenty przeciw temu rozwiązaniu.

Najsilniejsze obawy kandydatów do przeszczepienia kończyn(y) związane z funkcjonalnością przeszczepu dotyczą tego, czy chory będzie po zabiegu w stanie samodzielnie funkcjonować. To właśnie w podyktowaniu tymi obawami badani długo zwlekali z decyzją o przystapieniu do procedury kwalifikacji na biorcę kończyny górnej. O tym, że ten proces decyzyjny nie był jednak dłużej rozciagany w czasie zadecydowały doświadczenia osób poddanych już przeszczepieniu ręki, o których chorzy dowiadywali się z mass mediów. Szczególnie zachęcające okazały się dla chorych informacje dotyczące zadowalającej biorców funkcji przeszczepionej kończyny w zakresie jej ruchomości i czucia, a więc tych efektów, na których chorym zależy najbardziej. Takich informacji badani nie mogli posiadać na podstawie uprzednich doświadczeń przeszczepienia im kończyny, których badani po prostu nie mieli. A zatem to nie na wiedzy na temat swoich własnych przeszłych dokonań w podobnej sytuacji kandydat na biorcę opiera swoje projektowanie. Decyzję o poddaniu się transplantacji kończyny podejmuje w oparciu o swoją wiedzę ale na temat czynów innych osób, które to czyny są w swoim typie podobne do czynu przez niego projektowanego (zob. S c h üt z 2012: 132). Wypada tutaj jeszcze wspomnieć o czymś, co w kontekście projektowania działania $\mathrm{Sch}$ ütz nazywa „horyzontem pustych antycypacji”, używając tego terminu w odniesieniu do „założeń, iż zaprojektowany czyn będzie realizowany w taki sam sposób, jak wszystkie wcześniejsze, podobne i znane aktorowi czyny" (2012: 135). Tylko jeden $\mathrm{z}$ badanych, z racji na przeszłe doświadczenie przeszczepienia mu kończyny ${ }^{7}$, projektując powtórne poddanie się tej metodzie leczenia mógł odwołać się do po-

${ }^{7}$ Pierwszy zabieg transplantacji kończyny u tego chorego został uznany za nieudany z medycznego punktu widzenia. W przeszczepionej kończynie pojawił się problem zakrzepicy żył, wskutek którego po półtora miesiąca od zabiegu transplantolodzy podjęli decyzję o amputacji przeszczepu. Chory ponownie trafił na listę chorych oczekujących na ten rodzaj transplantacji. Informacje te autorka tekstu uzyskała w trakcie wywiadów pogłębionych z ekspertami instytucjonalnymi (transplantologami i chirurgami), które zostały przeprowadzone na Oddziale Chirurgii Ogólnej Szpitala Powiatowego im. św. Jadwigi Śląskiej w Trzebnicy. 
siadanej w tym kontekście wiedzy i dokonując pewnej idealizacji powiedzieć za Husserlem I can do it again („mogę zrobić to powtórnie”) (H u s s e r 1 1929, za: S ch ütz 2006: 877). Ta wiedza pozwala temu konkretnemu badanemu poczuć się dojrzalszym (grew older) w zaprojektowanym działaniu, gdyż jego uprzedni podobny projekt został zmaterializowany ( $\mathrm{S} \mathrm{ch}$ üt z 2012: 133).

Mimo doświadczanych obaw i wątpliwości, od których badani jako kandydaci do przeszczepienia kończyny nie są wolni, transplantację postrzegają jako jedyne słuszne rozwiązanie swojego cielesnego problemu. Po przeanalizowaniu swojej sytuacji zdrowotnej i rozważeniu możliwych sposobów postępowania obierają kierunek swojego dalszego działania. Co ważne, argumenty dotyczące negatywnych następstw immunoterapii nie stanowią o treści obaw kandydatów na biorców ręki. W ocenie badanych są one postrzegane jako te, które mają zdecydowanie mniejszy negatywny wpływ na ich przyszłą somatopercepcję aniżeli deficyt kończyny. W żaden sposób według ich relacji nie mogą one zatem zaważyć na podjętej już decyzji o poddaniu się transplantacji. Powodzenie transplantacji uzależniają przede wszystkim od siebie samych, czyli najpierw uporu w dążeniu do zostania biorcą kończyny, a następnie ambitnej pracy podczas rehabilitacji. Respondenci są silnie zorientowani na transplantację kończyn(y). Niektórzy $\mathrm{z}$ nich formułując motywację transplantacyjną określali swój obecny stan jako „,̇ycie przeszczepieniem”, co podkreśla istotność tego celu. Sama perspektywa transplantacji sprawia, że badani snują plany i myślą o sobie w przyszłości.

\section{Zamiast zakończenia: refleksja między motywami „poniewä̇” a ,żeby"}

Motywy typu ,ponieważ” zrekonstruowałam w takim stopniu, w jakim ujawniły się one $\mathrm{w}$ wypowiedziach badanych. Zdaję sobie bowiem sprawę $\mathrm{z}$ tego, że swoją sytuację biograficzną badani mogli odsłonić tylko fragmentarycznie. Z pewnością badani ujawniali tylko niektóre aspekty ich biografii, które uznali za najważniejsze dla nich samych z punktu widzenia doświadczania własnego ciała. Jak pisze A Schütz, ,to nasza sytuacja biograficzna określa, co jest problemem w danym momencie, a zatem i system istotności, ze względu na który różne aspekty świata ujmowane są jako typowe" (2006: 882). Kwestia transplantacji kończyny górnej pozostaje dla badanych życiowym priorytetem, od realizacji którego zależy powodzenie innych celów życiowych. Chęć poddania się temu zabiegowi traktują jako coś naturalnego i oczywistego w sytuacji, w której się znaleźli. Dostrzegają w nim jedyną szansę na to, by doświadczyć jeszcze własnego ciała w kompletnej formie. Poznanie tych motywów wymagało retrospektywnej aktywności badanych w trakcie wywiadu, poprzez którą przypominali sobie przeszłe zdarzenia lub przeżycia, także te sięgające czasu sprzed amputacji. Na pełne jednak ich dostrzeżenie przez badanych można liczyć jednak dopiero wtedy, gdy 
dojdzie już do aktu przeszczepienia kończyny, a więc działanie biorcy stanie się czynem. „Tylko wówczas, gdy działanie zostało zakończone [...] może on zwrócić się w stronę swego przeszłego działania z perspektywy obserwatora samego siebie, i zbadać, jakie okoliczności wpłynęły na to, co uczynił" (S c h ütz 2012: 134). Zwłaszcza, że konkluzji opisanych powyżej motywów i oczekiwań potencjalnych biorców kończyny do głosu dochodzą dwa paradoksy: 1) mimo pogodzenia się badanych z ograniczeniami sprawnościowymi sfragmentaryzowanego ciała (motyw „ponieważ”, to właśnie odbudowa sprawności pozostaje ich najważniejszym motywem transplantacyjnym (motyw ,żeby”); 2) mimo zasadniczej nieakceptacji wizerunkowej sfragmentaryzowanego ciała (motyw „ponieważ”), kwestia jego potransplantacyjnej estetyki jest w motywach badanych relatywnie mniej znacząca (motyw ,żeby”). Należy wszak pamiętać, że w czasie przeprowadzania badań przez autorkę, żaden z badanych jeszcze nie zmaterializował swojego projektu. Dopóki działanie kandydata na biorcę przeszczepu kończyny górnej trwa, tymi motywami, które najbardziej go zajmują, są motywy ,żeby”.

\section{Bibliografia}

Cheł m oń s k i A., Ja błe c k i J. (2 01 ), Kwalifikacja biorców kończyny górnej, [w: ] Z. K u z y s z y n (red.), Społeczno-etyczne aspekty transplantologii, Wydawnictwo Continuo, Wrocław, s. $43-46$.

J a błe c k i J.,C h eł m oń s k i A. (2 01 ), Społeczno-etyczne aspekty transplantacji kończyny gór$n e j$, [w:] Z. . K u z y s z y n (red .,) Społeczno-etyczne aspekty transplantologii, Wydawnictwo Continuo, Wrocław, s. 47-59.

K a u fm a n n J.-C. (2010), Wywiad rozumiejacy, Oficyna Naukowa, Warszawa.

K o n e c k i K. (2000), Studia z metodologii badań jakościowych. Teoria ugruntowana, Wydawnictwo Naukowe PWN, Warszawa.

K o w a 1 K. (2014), Przeżycia fantomowe u osób z deficytem kończyn(y) - perspektywa fenomenologiczna, „Hygeia Public Health”, nr 49 (1), s. 91-97.

Le i b n i z G. W. (2001), Teodycea. O dobroci Boga, wolności człowieka i pochodzeniu zła, Wydawnictwo Naukowe PWN, Warszawa.

Merleau-P onty M \& 001 Fenomenologia percepcji, Fundacja Aletheia, Warszawa.

Przy b yło w s k a I. (1 97 \&) Wywiad swobodny ze standaryzowana lista poszukiwanych informacji i możliwości jego zastosowania w badaniach socjologicznych, „Przegląd Socjologiczny”, t. 30 , s. 53-68.

S c hütz A. (2006), Potoczna i naukowa interpretacja ludzkiego działania, [w:] A. J a s iń s k a - K a n i a, L. M. Ni ja k o w s ki, J. S z a c k i, M. Z i ółk o w s ki (wybór i oprac.), Współczesne teorie socjologiczne, t. 2, Wydawnictwo Naukowe „Scholar”, Warszawa, s. 867-893.

S c hüt z A. (2012), O wielości światów. Szkice z socjologii fenomenologicznej, Zakład Wydawniczy „Nomos”, Kraków.

S z a ck i J. (2006), Socjologia fenomenologiczna, [w:] A. J a s iń s k a-K a n i a, L. M. Nij a k o w s k i, J. S z a c k i, M. Z i ółk o w s k i (wybór i oprac.), Współczesne teorie socjologiczne, t. 2, Wydawnictwo Naukowe „Scholar”, Warszawa, s. 863-866.

We ber M. (1947), The Theory of Social and Economic Organization, Oxford University Press, New York. 


\section{Katarzyna Kowal}

\section{EXPECTATIONS AND MOTIVATION FOR TRANSPLANTATION OF POTENTIAL UPPER LIMB RECIPIENTS - PHENOMENOLOGICAL SOCIOLOGY THEORETICAL AND RESEARCH STUDY}

Summary. Issues discussed in the paper are located on the borderline between sociology and medicine. The aim of the paper is to present expectations and motives of patients with the absence of hand with regard to their potential hand transplant surgery. These motives and expectations were studied in the context of the patients' previous experience of the function and visual image of the fragmented body versus their future experience of the function and visual image of the reconstructed body. The empirical basis of the paper is sociological qualitative research conducted in the group of candidate recipients who were qualified for unilateral or bilateral transplantation of the upper limb in Poland $(\mathrm{N}=5)$. The selected theoretical frame of reference for the thus defined research topics were elements of Alfred Schütz's phenomenological sociology, and more precisely his theory of "in-order-to motives" and "because motives". The analysis of the empirical material confirmed the existence of both categories of motives in the transplantation project of the investigated potential upper limb recipients. The most important "because motives" appeared to be those connected with: non-acceptance of the image of their own bodies; social perception of their disability; limitations in the bodily function. The key "in-order-to motives" for transplantation are: reconstruction of the bodily function; regaining of the aesthetic image of their own body. In conclusion to the thus formulated motives and expectations two important findings were made: despite the research subjects' acceptance of the limited function of their fragmented body, regaining of function remains the most important motive for transplantation; despite the basic non-acceptance of the image of their fragmented body, the issue of post-transplantation aesthetic appearance of the body is relatively less significant as a motive for transplantation.

Keywords: sociology of medicine, limb transplantation, hand transplant, phenomenology, body experience, "because motives", "in-order-to motives". 